\title{
LOAD-DEFLECTION BEHAVIORS AND PLASTIC FATIGUE OF WIDE-FLANGE BEAMS SUBJECTED TO ALTERNATING PLASTIC BENDING
}

\author{
PART III STEADY-STATE THEORY
}

\author{
By RYO TANABASHI ${ }^{1)}$, YOSHITSURA YOKOO ${ }^{1)}$, \\ and TSUNEYOSHI NAKAMURA ${ }^{2)}$ \\ Members of A.I.J.
}

\section{INTROUCTION}

Previous theoretical predictions of load-deflection behaviors of wide-flange beams, columns and frames are mostly based upon bilinear or polylinear hysteretic stress-strain relations assumed without sufficient quantitative evidences and concerned primarily with initial transient behaviors [(I-3 10)] Nonlinear stress-strain relations have been applied only to virgin response [1], [2]. With the use of modern electronic computers and of the finite difference or finite element method, it does not appear to be very difficult to obtain numerical solutions to the load-deflection behaviors of, at least, members subjected to alternating plastic bending under the presence of an axial force [3], [4].

The purpose of the present paper is to derive an approximate but analytical solution to the steadystate load-deflection behaviors and energy absorption capacity based upon the concept of the steadystate alternating plastic bending and the concept of an approximately equivalent sandwich cross section. In view of the experimental evidence obtained in Part $I$, the flanges of the idealized sandwich section of a specimen may be assumed, to the first order approximation, to be subjected to alternating tension and compression of an equal strain amplitude in steady-state alternating bending. The skeleton and hysteretic stress-strain relations which have been derived in Part II are therefore applied. It will be shown that the numerical result obtained from the present theory predicts the experimental load-deflection curves, energy absorption per cycle considerably well. Since the maximum absolute strain ampli-

E: tudes can also be estimated by the present theory, a prediction on the plastic bending fatigue ductility relation will also be made on the assumption that the tension-compression fatigue ductility relation derived in Part II may be applied to flanges of wide-flange specimens.

\section{ASSUMPTIONS FOR APPROXIMATE ANALYSIS}

The bending strain distributions shown in Figs. 5 and 6 of Part I have clearly indicated the existence of steady-state bending strain distributions. It should be noted, however, that the steady-state bending strain distributions in specimens subjected to larger deflection amplitudes are the results which

5 include the effect of local and lateral deformations. It is observed that, the steady-state bending strain distribution in a specimen subjected to a smaller deflection amplitude is almost the same in upward and downward bending but that it has a larger amplitude in the direction of the virgin bending in a specimen subjected to a larger deflection amplitude. It is not clear from the experimental evidence so far obtained, whether this circumstance is solely due to the initial perfectly plastic behavior or to the lateral torsional deformation. Since, however, the plastic region in a specimen subjected to a smaller deflection amplitude has been indeed subjected to tension and compression of an almost equal strain amplitude, it is a reasonable first-order approximation to assume that a steady-state bending strain

1) Professors and 2) Assistant Professor, respecively, of Architecture, Kyoto University, Kyoto 
distribution has an equal amplitude in downward and upward bending. Deviation of the observed distribution from the assumed distribution may be regarded to be of a second order quantity. This assumption implies that, the steady-state stress distribution in a specimen at the prescribed maximum or minimum deflection configuration is governed by the skeleton stress-strain relations which have been derived in Part II. The stress distribution over a cross-section in a plastic region based upon Eq. (1) of Part II is as shown in Fig. 1 (b), if the elastic response is not to exhibit any softening behavior up to $\varepsilon=\varepsilon_{y}$ in the converging process to the skeleton curve given by Eq. (1), while the stress distribution based upon Eq. (5) of Part II is as shown in Fig. 1 (d). Although the sharp peak in Fig. 1 (b) is hypothetical, the form of Eq. (1) is advantageous in deriving a hysteretic load-deflection relation. On the other hand, Eq. (5) which appears to be more realistic, will be useful only for a skeleton load-deflection relation. The principal advantage of the above assumtion is that an analytical steady-state solution may be derived in an explicit and closed form with the use of the "approximately equivalent sandwich section" defined below.

An idealized sandwich section consists of two flanges of concentrated areas carrying normal stresses only and a shear resistant core which does not carry normal stress. A sandwich section is said to be equivalent to the original wide-flange section if (1) the extreme fiber strains $\pm \varepsilon_{a}$ and the curvature $\kappa$ at the section are the same and (2) the corresponding extreme fiber stresses $\pm \sigma_{a}$ and the bending moments are the same. Due to the nonlinear stress-strain relation fitting considerably well to the experimental result, the equivalent section is dependent upon the nonlinear stress distribution. It is more convenient to define an approximately equivalent sandwich section which may be applied throughout a plastic region without regard to nonlinear stress distributions. The approximately equivalent sandwich section is defined as that section which has the original depth $H$ and the equivalent concentrated flange area only at the particular section where $\sigma_{a}=\sigma_{y}$ and $\varepsilon_{a}=\varepsilon_{y}+\varepsilon_{p y}$. It is called "approximately equivalent" since the aforementioned conditions are satisfied only approximately at sections other than the particular section.

The equivalence conditions can be satisfied precisely throughout an elastic region. The concentrated area of a flange of the equivalent sandwich section in an elastic region is given by

$$
A_{e} H=Z_{e}
$$

where $Z_{e}$ denotes the elastic section modulus. The concentrated area of the approximately equivalent sandwich section associated with the stress distribution shown in Fig. 1 (b), is given by

$$
A_{p}=\left[\frac{\sigma_{F}}{\sigma_{y}}\right]\left(B-t_{1}\right)\left[1-\frac{t_{2}}{H}\right] t_{2}+\left[\frac{\sigma_{R}}{\sigma_{y}}\right](4-\pi)\left[\frac{1}{2}-\frac{t_{2}+c}{H}\right] R^{2}+\frac{1}{2} f_{w} t_{1} H
$$

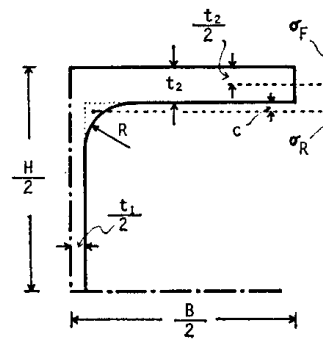

(a) Cross-section
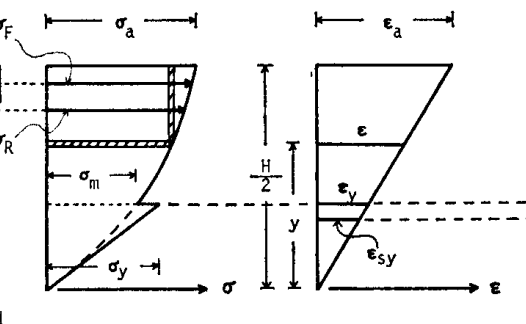

(c) Strain Distribution

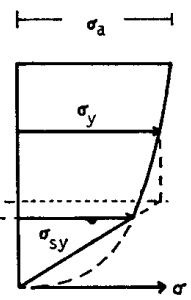

(d) Stress Distribution

Fig.-1 Idealized Stress Distribution in a Steady-state

The symbols appearing in this equation are defined in Fig. 1. The average stresses $\sigma_{F}$ in a flange and $\sigma_{R}$ in a round corner may be evaluated by the standard Taylor expansion of $\varepsilon(\sigma)$ about $\sigma=\sigma_{y}$ as follows :

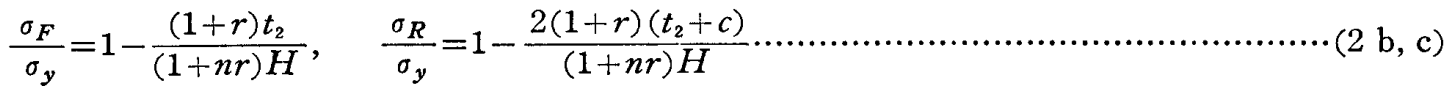

where $r=\varepsilon_{p y} / \varepsilon_{y}$, as was defined in Part II.

The third term representing the contribution of the web stresses to the resultant moment may be 
evaluated by an integration similar to that employed in Ref. $[1,2]$ and $f_{w}$ is given by

$$
\begin{aligned}
f_{w}= & \frac{1}{3(1+r)^{2}}\left\{2+\frac{3(1+n) r}{n+2}+\frac{3 n r^{2}}{2 n+1}\right\}+ \\
& \frac{1}{2(1+r)^{2}}\left[\frac{\sigma_{m}}{\sigma_{y}}\right]\left\{\frac{1}{3}\left[\frac{\sigma_{m}}{\sigma_{y}}\right]+\frac{2 r}{n+2}\left[\frac{\sigma_{m}}{\sigma_{y}}\right]^{n+1}+\frac{r^{2}}{2 n+1}\left[\frac{\sigma_{m}}{\sigma_{y}}\right]^{2 n}-1\right\}
\end{aligned}
$$

where

$$
\left[\frac{\sigma_{m}}{\sigma_{y}}\right]+r\left[\frac{\sigma_{m}}{\sigma_{y}}\right]^{n}=1 \quad\left(\sigma_{m}>0\right)
$$

The resultant moment corresponding to this stress distribution is denoted by $M_{y}$, while that of elastic stress distribution with the extreme fibre stress $\sigma_{y}$ by $M_{0}$. The ratio $M_{y} / M_{0}$ is denoted by $\mu_{0}$. It is noted that $A_{p} / A_{e}=\mu_{0}$.

The concentrated area of the approximately equivalent sandwich section associated with the stress distribution shown in Fig. 1 (d) may also be represented by Eq. (2a) if $n$ is replaced by $\bar{n}$ in Eq. $\left(2 \mathrm{~b}\right.$ and $\mathrm{c}$ ) and if $f_{w}$ is estimated by

$$
f_{w}=\frac{1}{3(1+r)^{2}}+\frac{\bar{n}}{2 \bar{n}+1}\left[1-\frac{r_{s}^{3}}{(1+r)^{2}}\right]
$$

The resultant moment corresponding to this stress distribution is denoted by $M_{s}$ and the ratio $M_{s} / M_{0}$, by $\mu_{s}$.

\section{STEADY-STATE SOLUTION}

3.1 SKELETON LOAD-DEFLECTION CURVE-1 In accordance with the foregoing assumptions and idealization, a beam has the flange area $A_{e}$ in an elastic region and $A_{p}$ in a plastic region, and is subjected to alternating bending as a cantilever shown in Fig. 2(c). The coordinate system and symbols to be used are shown in Fig. 2. It is convenient to introduce the following dimensionless quantities :

$$
\xi=\frac{x}{L}, \quad \eta=\frac{y}{L}, m=\frac{M}{M_{y}}, q=\frac{Q L}{M_{y}}
$$

The lower flange stresses in the elastic and plastic regions may then be written as

$$
\begin{aligned}
& \frac{\sigma}{\sigma_{y}}=\frac{A_{p}}{A_{e}} \frac{\sigma A_{e} H}{\sigma_{y} A_{p} H}=\mu_{0} m=\mu_{0} \frac{Q x}{M_{y}}=\mu_{0} q \xi \\
& \frac{\sigma}{\sigma_{y}}=\frac{\sigma A_{p} H}{\sigma_{y} A_{p} H}=m=q \xi
\end{aligned}
$$

respectively. The curvature-displacement relation may be reduced to

$$
\kappa L=L \frac{d^{2} y}{d x^{2}}=\frac{d^{2} \eta}{d \xi^{2}}=\eta^{\prime \prime}
$$

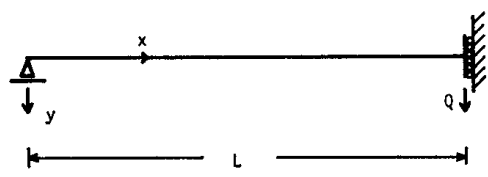

(a) COORDINATE SYSTEM

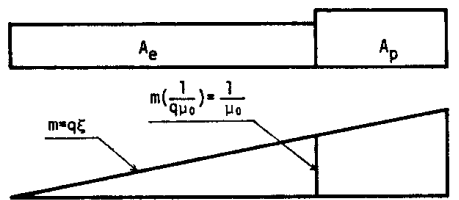

(b) AREAS OF EQUIVALENT SANDWICH SECTIONS

(c) BENDING MONENT

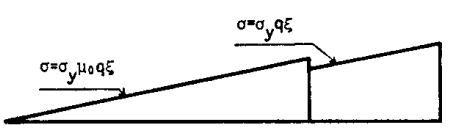

(d) FLANGE STRESSES

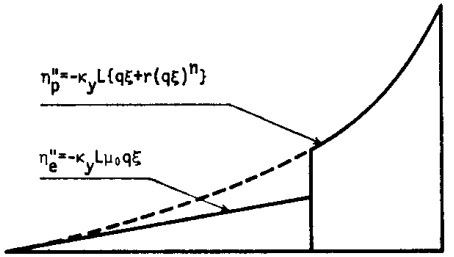

(e) CURVATURE

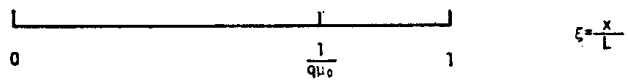

Fig.-2

where a prime denotes differentiation with respect to $\boldsymbol{\xi}$.

After a steady-state has been attained in a few cycles of alternating plastic bending, the state of stress in a flange at a maximum deflection may be considered to be governed by the skeleton stressstrain relation. The variation of the state of stress as the load and deflection are varied, must be considered to be governed by the hysteretic stress-strain relation.

If it may be assumed that no softening occurs in the elastic region and that the skeleton stressstrain relation

$$
\frac{\varepsilon}{\varepsilon_{y}}=\frac{\sigma}{\sigma_{y}}\left[1+r\left|\frac{\sigma}{\sigma_{y}}\right|^{n-1}\right]
$$


which has been derived in Part II, can be applied only to the :plastic region in the steady state, then the corresponding skeleton load-deflection relation may be obtained as follows.

The elastic region is defined by

$$
0 \leq|M| \leq M_{0} \text { or } 0 \leq \xi \leq 1 /|q| \mu_{0}
$$

The diflerential equation governing the deflection $\eta_{e}$ in the elastic region may be written, in view of Eq. (4), as

$$
-\frac{\eta_{e}^{\prime \prime}}{\kappa_{y} L}=\frac{\varepsilon}{\varepsilon_{y}}=\frac{\sigma}{\sigma_{y}}=\mu_{0} q \xi
$$

Substitution of Eq. (5) into Eq. (7) and use of Eq. (6) provide the differential equation governing the deflection $\eta_{p}$ in the plastic region.

$$
-\frac{\eta_{p}^{\prime \prime}}{\kappa_{y} L}=\frac{\varepsilon}{\varepsilon_{y}}=\frac{\sigma}{\sigma_{y}}\left\{1+r\left|\frac{\sigma}{\sigma_{y}}\right|^{n-1}\right\}=q \xi\left\{1+r|q \xi|^{n-1}\right\}
$$

The general solutions to Eq. (9) and (10) may readily be obtained. Integration constants can be determined by the boundary conditions $\eta_{e}(0)=0$ and $\eta_{p}{ }^{\prime}(1)=0$ and the continuity conditions $\eta_{e}\left(1 /|q| \mu_{0}\right)$ $=\eta_{p}\left(1 / q \mid \mu_{0}\right)$ and $\eta_{e}^{\prime}\left(1 /|q| \mu_{0}\right)=\eta_{p}{ }^{\prime}\left(1 /|q| \mu_{0}\right)$. The solution $\eta_{p}(\xi)$ may be written as

$$
\eta_{p}=-\kappa_{y} L q\left\{\left(\frac{\xi^{3}}{6}-\frac{\xi}{2}\right)+\frac{r|q|^{n-1}}{n+1}\left[\frac{\xi^{n+2}}{n+2}-\xi\right]+\frac{1-\mu_{0}}{3|q|^{3} \mu_{0}^{3}}+\frac{r}{n+2} \frac{1}{|q|^{3} \mu_{0}^{n+2}}\right\}
$$

The deflection amplitude $\eta_{p}(1)=\delta_{a}$ for a load amplitude $q_{a}$ is given by

$$
\delta_{a}=\kappa_{y} L q_{a}\left\{\frac{1}{3}\left[1+\frac{\mu_{0}-1}{\left|q_{a}\right|^{3} \mu_{0}^{3}}\right]+\frac{r\left|q_{a}\right|^{n-1}}{n+2}\left[1-\frac{1}{\left|q_{a}\right|^{n+2} \mu_{0}{ }^{n+2}}\right]\right\}
$$

$$
\left(\left|q_{a}\right| \geq 1 / \mu_{0}\right)
$$

If the beam is entirely elastic, then $A=A_{e}$ throughout and the deflection is given by

$$
\delta_{a e}=\frac{1}{3} \kappa_{y} L q_{a} \mu_{0}
$$

The plastic component $\delta_{a p}$ of the deflection has been called the plastic deflection and is defined as the difference $\delta_{a}-\delta_{a \ell}$. The expression of $\delta_{a p}$ may be reduced to

$$
\delta_{a p}=\kappa_{y} L q_{a}\left\{-\frac{1}{3}\left(\mu_{0}-1\right)\left[1-\frac{1}{\left|q_{a}\right|^{3} \mu_{0}^{3}}\right]+\frac{r\left|q_{a}\right|^{n-1}}{n+2}\left[1-\frac{1}{\left|q_{a}\right|^{n+2} \mu_{0}^{n+2}}\right]\right\}
$$

The curve described by Eq. (12) is the skeleton load-deflection curve. It should be noted that Eq. (12) does not represent the load-deflection curve in the usual sense and only gives the load amplitude for a prescribed deflection amplitude. Eq. (11) represents the deflected shape at the state of load and deflection expressed by a tip of a hysteresis curve.

3.2 HYSTERETIC LOAD-DEFLECTION CURVE If the load-deflection curve of a beam starting from a state of deflection $\left(\delta_{a}>0, q_{a}>0\right)$ on the skeleton load-deflection curve passes through its symmetric point $\left(-\delta_{a},-q_{a}\right)$ on the skeleton curve when subjected to reversed bending and if the state of deformation at $\left(-\delta_{a},-q_{a}\right)$ is the precise reverse of that at $\left(\delta_{a}, q_{a}\right)$, then there exists indeed a closed hysteretic load-deflection curve in the steady-state. The lower flange stress and strain at $(\delta, q)$ denoted by $\sigma(\xi)$ and $\varepsilon(\xi)$, respectively are governed by the hysteretic stress-strain relation;

$$
\frac{\varepsilon(\xi)-\varepsilon_{a}(\xi)}{2 \varepsilon_{y}}=\frac{\sigma(\xi)-\sigma_{a}(\xi)}{2 \sigma_{y}}\left\{1+r\left|\frac{\sigma_{a}(\xi)}{\sigma_{y}}\right|^{n-n^{\prime}}\left|\frac{\sigma(\xi)-\sigma_{a}(\xi)}{2 \sigma_{y}}\right|^{n^{\prime}-1}\right\}
$$

which has been derived in Part II. If the curvature and bending moment distributions at $\left(\delta_{a}, q_{a}\right)$ and at a subsequent state $(\delta, q)$ are denoted by $\kappa_{a}(\xi), \kappa(\xi)$ and $m_{a}(\xi)$ and $m(\xi)$, respectively, then the curvature-moment relation may be reduced to

$$
\frac{\kappa(\xi)-\kappa_{a}(\xi)}{2 \kappa_{y}}=\frac{m(\xi)-m_{a}(\xi)}{2}\left\{1+r\left|m_{a}(\xi)\right|^{n-n^{\prime}}\left|\frac{m(\xi)-m_{a}(\xi)}{2}\right|^{n^{\prime}-1}\right\}
$$

The differential equation governing the deflection $\eta_{p}(\xi)$ in the plastic region may be written as

$$
\eta_{p}{ }^{\prime \prime}-\eta_{a}^{\prime \prime}=-2 \kappa_{y} L\left[\frac{q-q_{a}}{2}\right]\left\{\xi+r q_{a}{ }^{n-n^{\prime}}\left|\frac{q-q_{a}}{2}\right|^{n^{\prime}-1} \xi^{n}\right\}
$$

where $\eta_{a}$ denotes the deflection function at $\left(\delta_{a}, q_{a}\right)$. It should be noted that the power of $\xi$ in the nonlinear term is again $n$. The general solutions to Eq. (17) and for the elastic region may readily 
be obtained. Use of the boundary and continuity conditions in the general solutions furnishes the deflection at a subsequent state $(\delta, q)$ and the hysteretic load-deflection relation as follows :

$$
\begin{aligned}
\eta_{p}-\eta_{a}= & -2 \kappa_{y} L\left[\frac{q-q_{a}}{2}\right]\left\{\left[\frac{\xi^{3}-3 \xi}{6}-\frac{\mu_{0}-1}{3 q_{a}^{3} \mu_{0}^{3}}\right]\right. \\
& \left.+r q_{a}{ }^{n-n^{\prime}}\left|\frac{q-q_{a}}{2}\right|^{n^{\prime}-1}\left[\frac{1}{(n+1)}\left(\frac{\xi^{n+2}}{n+2}-\xi\right)+\frac{1}{(n+2) q_{a}^{n+2} \mu_{0}{ }^{n+2}}\right]\right\} \cdots \cdots \cdots \\
\delta-\delta_{a}= & \kappa_{y} L\left(q-q_{a}\right)\left\{\frac{1}{3}\left[1+\frac{\mu_{0}-1}{q_{a} \mu_{0}{ }^{3}}\right]+\frac{r q_{a}^{n-n^{\prime}}}{n+2}\left|\frac{q-q_{a}}{2}\right|^{n^{\prime}-1}\left[1-\frac{1}{q_{a}{ }^{n+2} \mu_{0}{ }^{n+2}}\right]\right\} \\
& \left(q_{a} \geqq 1 / \mu_{0}\right)
\end{aligned}
$$

It may readily be confirmed that the curve defined by Eq. (19) passes through the point $\left(-\delta_{a}\right.$, $\left.-q_{a}\right)$ and that $\eta_{p}(\xi)=-\eta_{a}(\xi)$ at $\left(-\delta_{a},-q_{a}\right)$. Similarly the load-deflection curve starting from ( $-\delta$, $-q_{a}$ ) may be shown to pass through $\left(\delta_{a}, q_{a}\right)$. Eq. (19) gives therefore a half of the steady-state hysteresis loop and the other half may be described by the equation similar to Eq. (19) in which $\delta-\delta_{a}$ and $q-q_{a}$ are replaced by $\delta+\delta_{a}$ and $q+q_{a}$, respectively. It may therefore be concluded that, once the state of deformation represented by $\pm \eta_{a}(\xi)$ is attained at $\left( \pm \delta_{a}, \pm q_{a}\right)$ through the converging process described in the preceding section, the subsequent load-deflection curve is a steady-state hysteresis loop consisting of the curve given by Eq. (19) and the other half. This hysteresis loop is the asymptote to which an actual load-deflection curve will approach after a number of cycles. It has been shown in Part I, that a beam apparently attains a steady state quite rapidly in a few cycles.

3.3 PLASTIC ENERGY DISSIPATION The plastic energy dissipated in a cantilever beam during a steady-state hysteretic cycle can be evaluated with the use of Eqs. (12) and (19). If the new coordinates $\bar{q}=q-q_{a}$ and $\bar{\delta}=\delta-\delta_{a}$ with the origin at the tip $\left(\delta_{a}, q_{a}\right)$ of a hysteresis loop are used, then the area $d_{p}$ enclosed by the hysteresis loop may be represented by

$$
d_{p}=M_{y}\left[4 q_{a} \delta_{a}-2 \int_{0}^{-2 q_{a}} \bar{\delta} d \bar{q}\right]
$$

Substitution of Eq. (12) and Eq. (19) into Eq. (20) provides

$$
d_{p}=\kappa_{y} L M_{y}\left[\frac{4 r}{n+2}\right]\left[\frac{n^{\prime}-1}{n^{\prime}+1}\right]\left[q_{a}^{n}-\frac{1}{q_{a}^{2} \mu_{0}{ }^{n+2}}\right] q_{a}
$$

$3.4 \delta_{a p} \sim N_{c}$ RELATION For a prescribed $\delta_{a}$, Eq. (12) determines $q_{a}$ and hence the strain at any point may be calculated by Eq. (5) and Eq. (7) or by Eq. (10). The largest extreme fiber strain for a prescribed $\delta_{a}$ occurs at $\xi=1$ and the total and plastic strain amplitudes are given by

$$
\begin{aligned}
\varepsilon_{a} & =\varepsilon_{y}\left(q_{a}+r q_{a}{ }^{n}\right) \\
\varepsilon_{a p} & =\varepsilon_{p y} q_{a}{ }^{n} \ldots \ldots \ldots
\end{aligned}
$$

respectively, in tension and compression. If these estimates of the largest strains are accurate and if the $\varepsilon_{a p} \sim N_{c}$ relation, Eq. (7) of Part II may be applied also to $\varepsilon_{a p}$ here, an idealized but approximate $\delta_{a p} \sim N_{c}$ relation can be derived therefrom.

3.5 SKELETON LOAD-DEFLECTION CURVE-2 If the skeleton stress-strain relation given by Eq. (5) of Part II :

$$
\left.\frac{\varepsilon}{\varepsilon_{y}}=(1+r)\left[\frac{\sigma}{\sigma_{y}}\right] \mid \frac{\sigma}{\sigma_{y}}\right]^{\vec{n}-1}
$$

is applied to the present problem, the corresponding stress distribution at a section in a plastic region is as shown in Fig. 1 (d). Through a manipulation similar to that of Section 3.1 , the skeleton loaddeflection relation may be obtained and reduced to

$$
\delta_{a}=\kappa_{y} L q_{a}\left\{\left[\frac{1+r}{\bar{n}+2}\right] q_{a^{\bar{n}-1}}+\left[\frac{1}{3 \mu_{s}^{2}}-\left(\frac{1+r}{\bar{n}+2}\right) \frac{1}{\mu_{s}^{\bar{n}+2}}\right] / q_{a}^{3}\right\}
$$

where $q_{a}=Q_{a} L / M_{s}>0$. The largest absolute extreme fibre strain must now be estimated by Eq. (5) of Part II rewritten above.

$$
\varepsilon_{a}=\varepsilon_{y}(1+r) q_{a}{ }^{\bar{n}}, \varepsilon_{a p}=\varepsilon_{y}(1+r) q_{a} \bar{n}-\varepsilon_{y} q_{a}
$$

\section{NUMERICAL RESULT AND DISCUSSION}

Table 1 summarises the cross-sectional properties, material properties and some nondimensionalized 


\section{Table 1}

\begin{tabular}{|c|c|c|c|c|c|c|c|c|c|c|c|}
\hline \multirow[b]{2}{*}{ Specimen No. } & \multicolumn{6}{|c|}{ Series A } & \multicolumn{5}{|c|}{ Series B } \\
\hline & 11 & 12 & 13 & 14 & 15 & 16 & 17 & 18 & 19 & 20 & 21 \\
\hline$M_{p} / \sigma_{y}\left(\mathrm{~cm}^{3}\right)$ & 91.4 & 92.6 & 91.5 & 92.0 & 90.4 & 84.8 & 89.4 & 88.3 & 88.6 & 89.3 & 88.9 \\
\hline$M_{p} \quad(t c m)$ & 264 & 258 & 265 & 258 & 268 & 238 & 256 & 249 & 254 & 251 & 251 \\
\hline$\sigma_{y}\left(t / \mathrm{cm}^{2}\right)$ & 2.89 & 2.79 & 2.90 & 2.81 & 2.97 & 2.80 & 2.87 & 2.82 & 2.87 & 2.81 & 2.83 \\
\hline$\varepsilon_{y}\left(x 10^{-3}\right)$ & 1.38 & 1.33 & 1.38 & 1.34 & 1.41 & 1.33 & 1.37 & 1.34 & 1.37 & 1.34 & 1.35 \\
\hline$\varepsilon_{y p}\left(x 10^{-3}\right)$ & 2.87 & 2.36 & 2.90 & 2.47 & 3.23 & 2.38 & 3.35 & 3.20 & 3.35 & 3.13 & 3.25 \\
\hline$r$ & 2.08 & 1.77 & 2.10 & 1.84 & 2.29 & 1.79 & $2: 52$ & 2.38 & 2.52 & 2.34 & 2.41 \\
\hline$n$ & \multicolumn{6}{|c|}{5.5} & \multicolumn{5}{|c|}{4.3} \\
\hline$M_{y} / \sigma_{y}\left(\mathrm{~cm}^{3}\right)$ & 88.1 & 89.2 & 88.1 & 88.7 & 87.1 & 81.9 & 86.1 & 85.1 & 85.4 & 85.9 & 85.6 \\
\hline$M_{y} \quad(t \mathrm{~cm})$ & 255 & 249 & 256 & 246 & 259 & 229 & 247 & 240 & 245 & 241 & 242 \\
\hline$M_{0} / \sigma_{y}\left(\mathrm{~cm}^{3}\right)$ & 79.9 & 80.7 & 78.7 & 80.3 & 78.7 & 74.5 & 78.0 & 77.1 & 77.2 & 77.8 & 77.5 \\
\hline$\mu_{0}$ & 1.103 & 1.105 & 1.106 & 1.104 & 1.107 & 1.100 & 1.103 & 1.103 & 1.106 & 1.103 & 1.105 \\
\hline$Q_{a} \quad$ (ton) & 1.45 & 1.49 & 1.58 & 1.57 & 1.66 & 1.54 & 1.56 & 1.63 & 1.65 & 1.50 & 1.44 \\
\hline$q_{a}=Q L / M_{y}$ & 1.023 & 1.079 & 1.108 & 1.149 & 1.151 & 1.211 & 1.135 & 1.222 & 1.210 & 1.116 & 1.072 \\
\hline$(\mathrm{mm})$ & 50 & 60 & 75 & 80 & 90 & 100 & 75 & 90 & 100 & 60 & 50 \\
\hline$\delta_{a}$ & 0.0278 & 0.0333 & 0.0416 & 0.0445 & 0.0500 & 0.0555 & 0.0416 & 0.0500 & 0.0555 & 0.0333 & 0.0278 \\
\hline$\delta_{\text {ap }}$ & 0.0089 & 0.0148 & 0.0217 & 0.0248 & 0.0289 & 0.0345 & 0.0213 & 0.0286 & 0.0338 & 0.0138 & 0.0087 \\
\hline $\bar{n}$ & & & 4.5 & & & & & & 3.8 & & \\
\hline$r_{S}$ & 0.723 & 0.746 & 0.719 & 0.746 & 0.701 & 0.745 & 0.640 & 0.650 & 0.640 & 0.661 & 0.647 \\
\hline$M_{s} / \sigma_{y}\left(\mathrm{~cm}^{3}\right)$ & 88.5 & 89.5 & 88.4 & 89.1 & 87.5 & 82.1 & 86.0 & 85.0 & 85.2 & 85.9 & 85.5 \\
\hline$(t \mathrm{~cm})$ & 256 & 250 & 256 & 249 & 260 & 230 & 247 & 240 & 244 & 241 & 242 \\
\hline
\end{tabular}

data from the test result of all the $\mathrm{H}$-specimens. The elastic and plastic section modulae have been computed from the cross-sectional dimensions which were measured by vernier calipers and micrometers. The yield stress may vary from specimen to specimen even within the same series. The tension-compression tests were conducted only on two series of plate specimens cut out of two different $\mathrm{H}$-specimens. Since the virgin load-deflection curve of every $\mathrm{H}$-specimen exhibited a perfectly-plastic behavior, however, the yield stresses were computed from the fully-plastic moments which were considered to have been attained. The yield stress of B-17 so computed is $2.87 \mathrm{t} / \mathrm{cm}^{2}$, while the average lower yield stress obtained from the tension-compression tests on B-17 plate specimens was $2.94 \mathrm{t} / \mathrm{cm}^{2}$. Since the material skeleton curves have been obtained only on one $\mathrm{H}$-specimen in a Series in Part II, it is assumed here that all the $\mathrm{H}$-specimens in a Series have the same material skeleton curve. From Fig. 5 of Part II, $\varepsilon_{p y}$ may then be read for each yield stress and $r=\varepsilon_{p y} / \varepsilon_{y}$ may be computed. The values of $M_{y} / \sigma_{y}$ and $M_{s} / \sigma_{y}$ were computed with the use of Eqs. (2) and measured cross-sectional dimensions. The averages of a pair of measured load amplitudes and plastic deflection amplitudes, respectively are also included in Table 1 as $Q_{a}$ and $\Delta_{a p}$ together with their dimensionless values.

The theoretical skeleton load-deflection curves for each $\mathrm{H}$-specimen may be drawn with the use of Eqs. (14) and (23). Figs. 3 (a) and (b) show the $\log -\log$ plots of the theoretical $q_{a} \sim \hat{o}_{a p}$ relations and the corresponding experimental points for Series $\mathrm{A}$ and $\mathrm{B}$, respectively. Since $M_{s}$ is very close to $M_{y}$ for all the $\mathrm{H}$-specimens as shown in Table 1 , an experimental load amplitude normalized with respect to $M_{s} / L$ has been regarded, in the scale of Fig. 3, to be the same as the amplitude normalized with respect to $M_{y} / L$. It is apparent that both of the theoretical curves predicted by Eq. (14) and (23) which are different from specimen to specimen fit the experimental points very well mostly within a few percent deviations and that the predictions due to Eq. (23) are slightly closer to experimental points.

Fig. 4 shows three theoretical hysteretic load-deflection curves given by Eq. (19) and the corresponding experimental curves to be compared with. Figs. 5 (a) and (b) show some theoretical [q- 

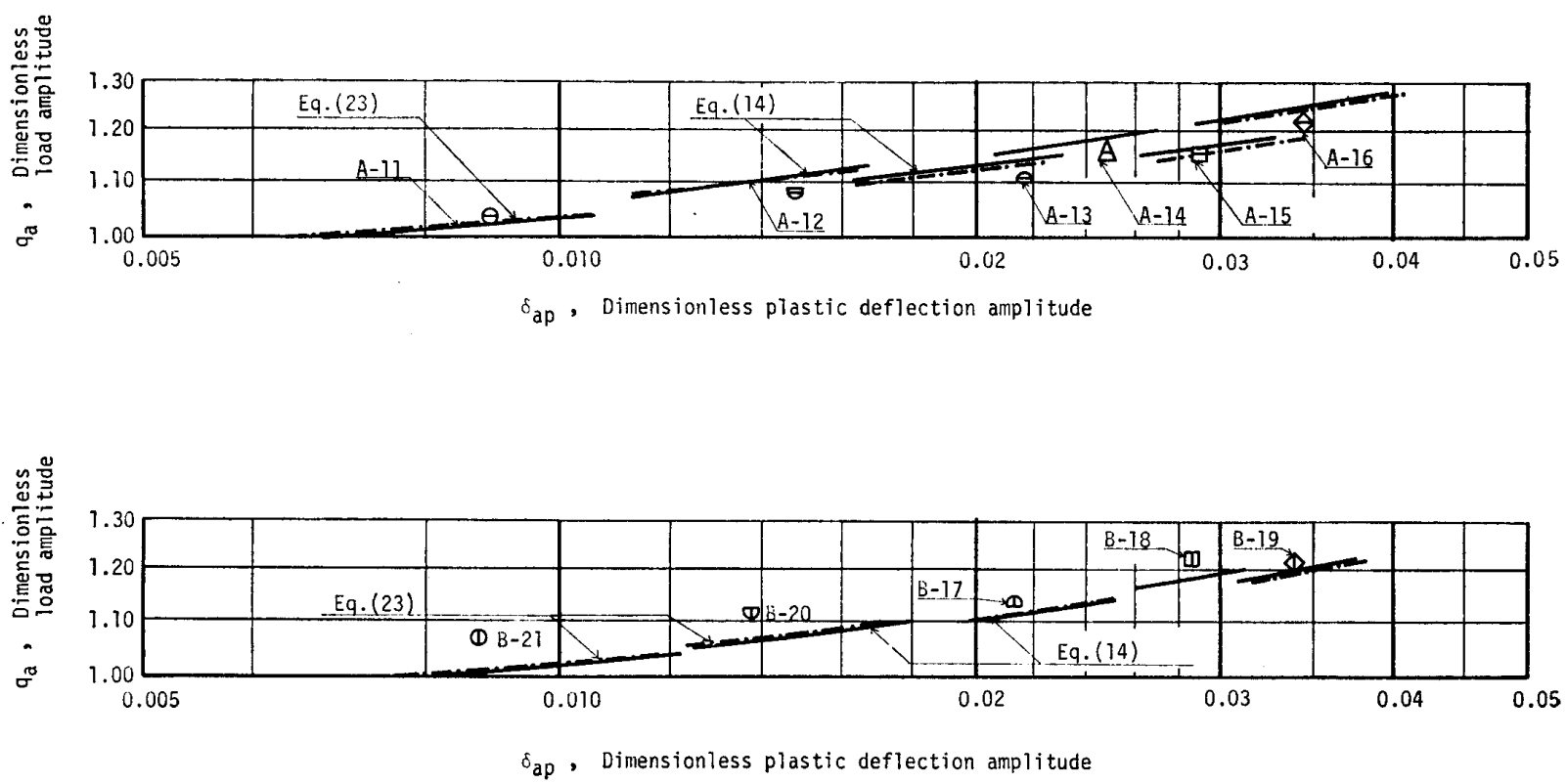

Fig. -3 a, b

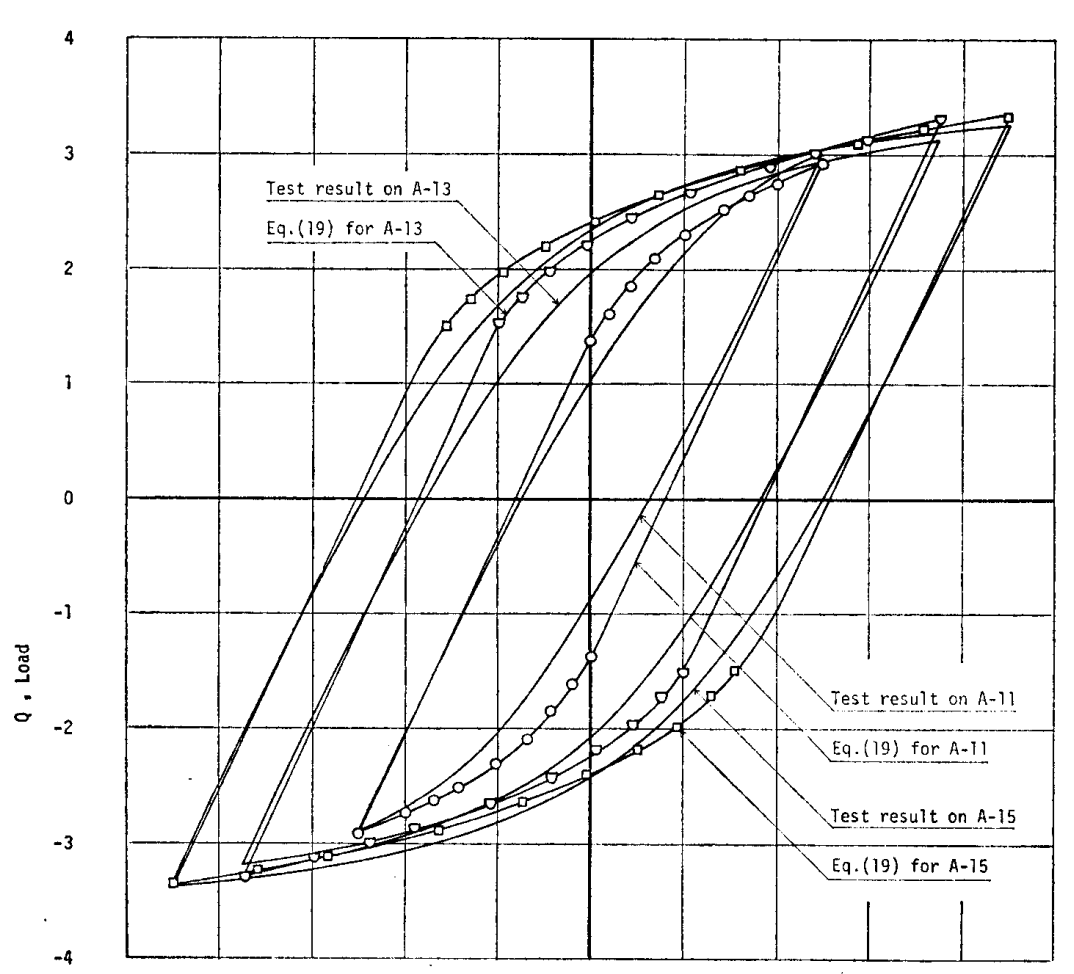

Fig. -4

$\left.q_{a}\right]-\left[\delta-\delta_{a p}\right]$ curves in $\log -\log$ scale to compare with nondimensionalized experimental points. Apparently, the theoretical curves predict the experimental result considerably well except near the shoulders which are sharper than those of experimental curves due to the sandwich approximation.

The plastic energy dissipated in a hysteretic cycle has been computed by means of Eq. (21) in the dimensionless form and plotted in Fig. 6. Since the theoretical hysteresis curves have sharper shoulders than the experimental curves as has been pointed out above, Eq. (21) overestimates the plastic energy. It is observed that the theoretical predictions are considerably close to the straight lines fitting the experimental points and that the deviations are mostly about $10 \%$ of the experimental values. Although no simple relation between $d_{p} / M_{y}$ and $\delta_{a p}$ can be derived from Eq. (14) and Eq. (21), it has been observed in the process of computation that the theoretical result is fairly close to the evaluation by means of the second term of Eq. (14), which is given by 


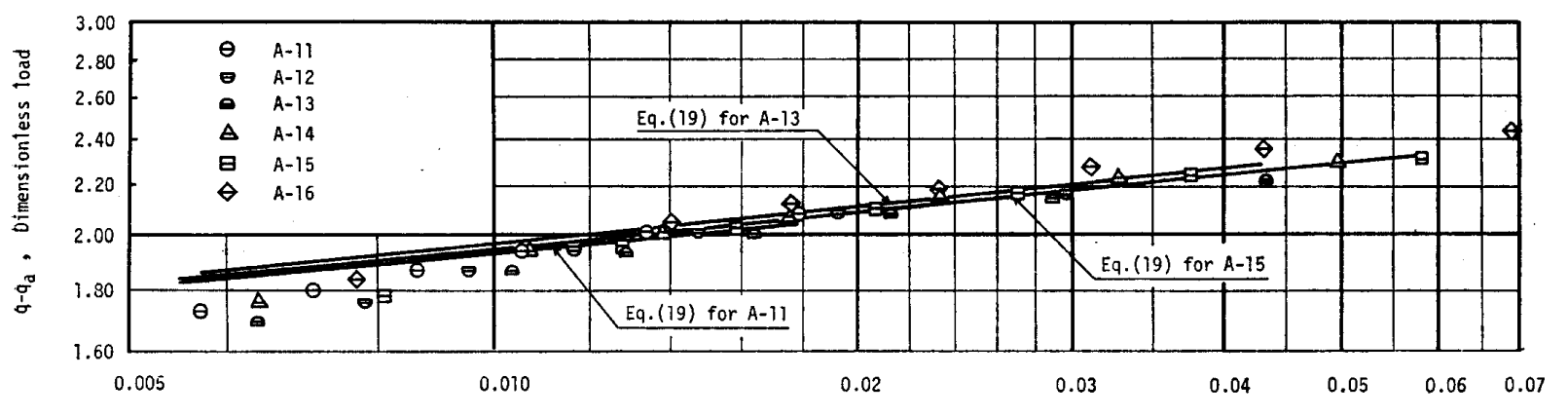

$\left[\delta-\delta_{a}\right]_{p}$, Dimensionless plastic deflection

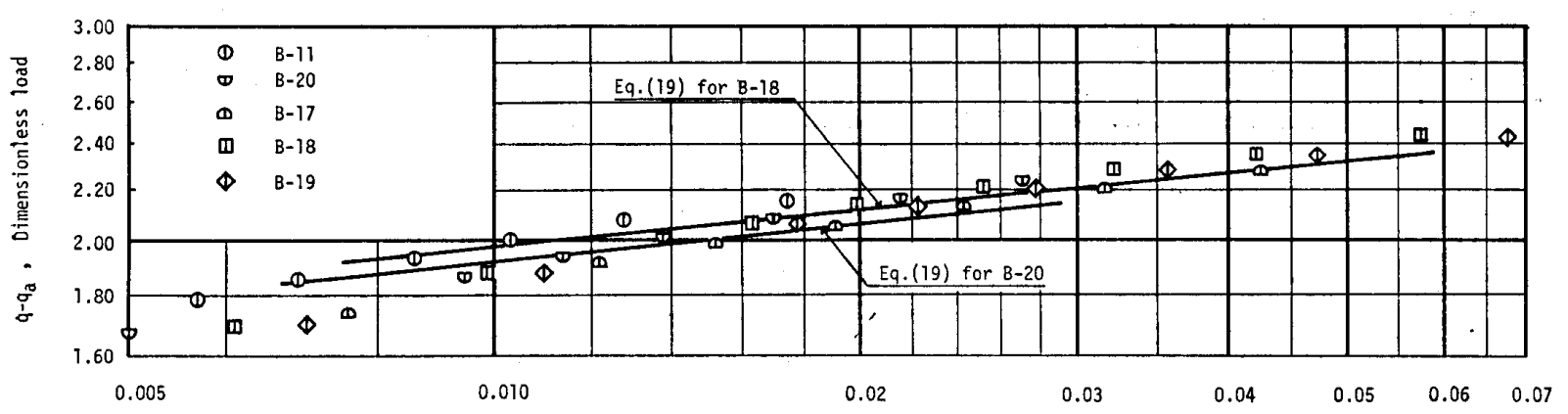

$\left[\delta-\delta_{a}\right]_{p}$, Dimensionless plastic deflection

Fig. -5 a, b

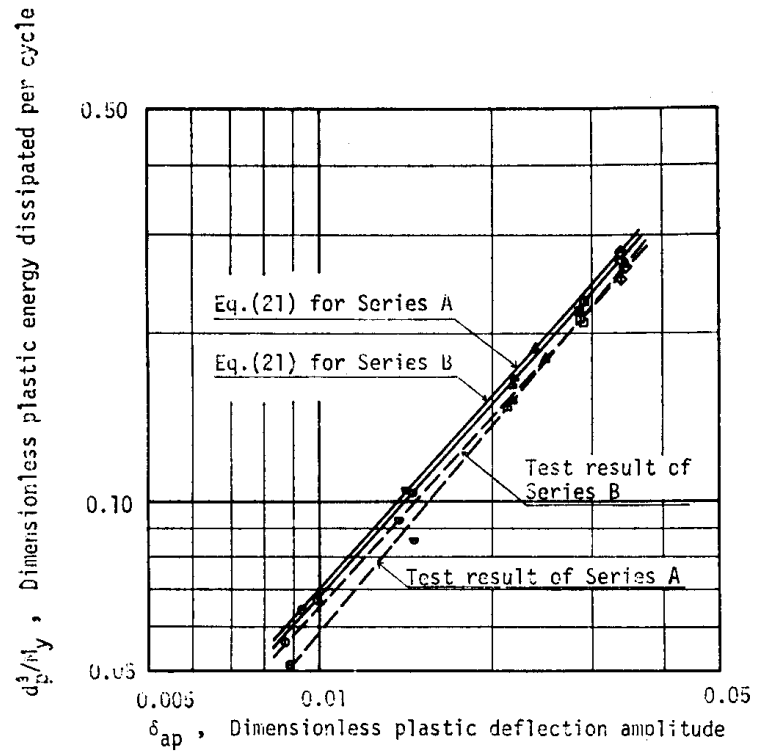

Fig. -6

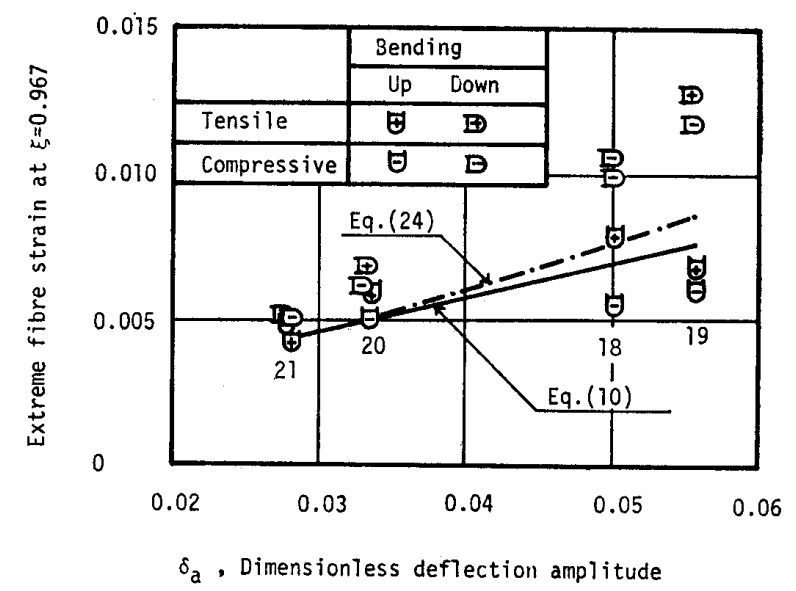

Fig.-7

$\frac{d_{p}}{M_{y}}=4\left[\frac{n^{\prime}-1}{n^{\prime}+1}\right] \delta_{a p} q_{a}$

Strains were measured at the sections located at $6 \mathrm{~cm}$ from the respective midspans. The theoretical estimates of strains must therefore be made for $\xi=0.967$. The solid and dot-dash lines in Fig. 7 are the theoretical estimates due to Eq. (10) and Eq. (24), respectively. Since the experimental points for specimens B-18 and B-19 show considerable scatter, it is difficult to estimate the essential deviation of the theoretical values from the experimental values. It may, however, be observed that the deviations from the average values of the experimental points are roughly within $20 \%$ of the average values.

If the largest extreme fibre strain may be assumed to obey the plastic fatigue ductility relation, Eq. (7) in Part II, then the theoretical $\delta_{a p} \sim N_{c}$ relations may be obtained for all the $\mathrm{H}$-specimens. The solid and dot-dash lines in Fig. 8 show the $\delta_{a p} \sim N_{c}$ curves computed from Eqs. (14) and (22) 


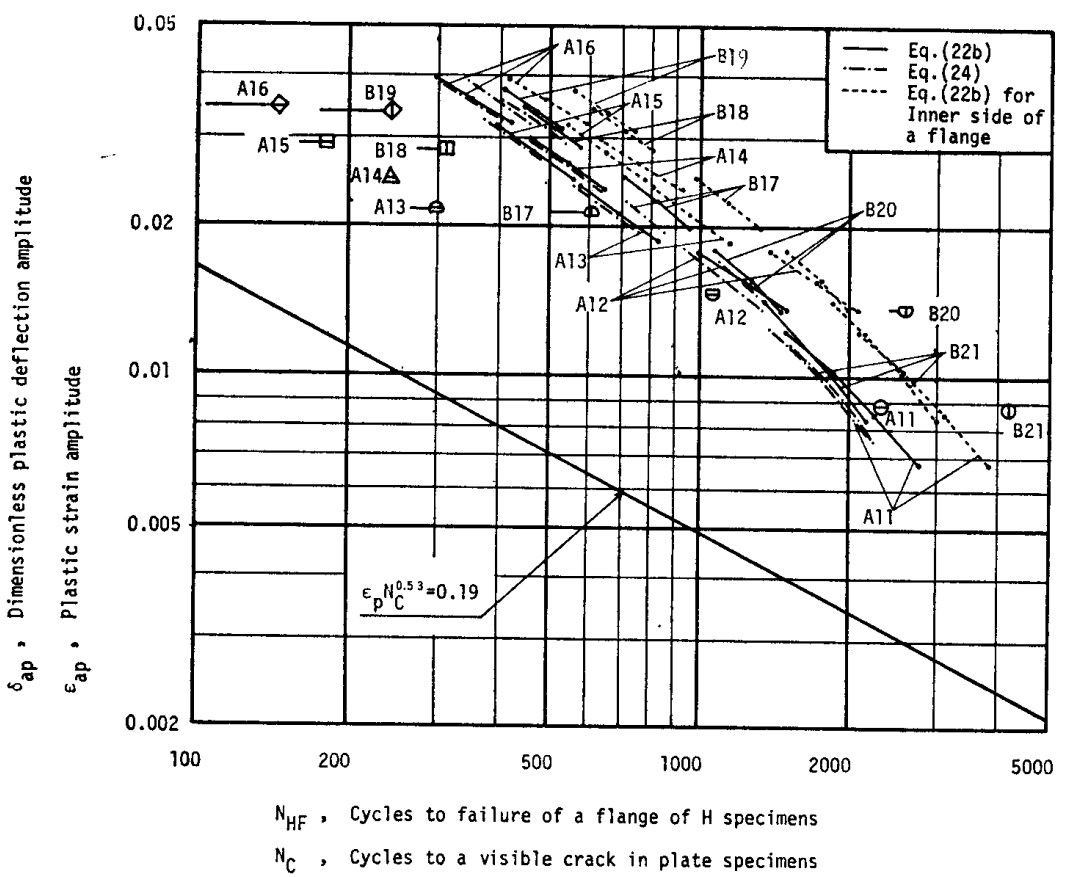

Fig.-8

and from Eqs. (23) and (24), respectively. Apparently the difference between the two estimates is only slight. These idealized $\delta_{a p} \sim N_{c}$ relations are based upon, among others, the assumptions that no local or lateral torsional deformation which would increase local strains occurs and that the effect of stress and strain gradients is of a second-order quantity. When the idealized $\delta_{a p} \sim N_{c}$ curves are compared with the experimental $\delta_{a p} \sim N_{H F}$ relations, it must be cautioned that the definition of $N_{H F}$ is different from that of $N_{c}$. It has already been pointed out in Part I that a number of hair cracks had been observed long before a deep crack penetrated through a flange of a $\mathrm{H}$-specimen. The detection of haircracks was made only with naked eyes and was not of a uniform accuracy. In spite of these reservations, the idealized $\delta_{a p} \sim N_{c}$ curves in Fig. 8 have revealed some features of the fatigue ductility of wide-flange members and explained partly the tendency that a pair of $\mathrm{H}$-specimens with different skeleton stress-strain relations exhibit different fatigue ductility relations even when subjected to the same deflection amplitude. Because of the difference of definitions of $N_{c}$ and $N_{H F}$, it may be of interest to draw $\delta_{a p} \sim N_{c}$ curves for the longitudinal strains at the inner sides of flanges. If these strains may be estimated from the linear distribution over a cross-section, the curves may be obtained by a simple translation of the previous $\delta_{a p} \sim N_{c}$ curves as shown by the dashed lines in Fig. 8.

\section{CONCLUSION}

The following conclusions may de drawn from the result :

(1) The steady-state theory proposed here as a first-order approximation is able to predict with a considerable accuracy the steady-state load-deflection behaviors of rolled wide-flange members subjected to alernating forced displacements. For specimens subjected to larger deflection amplitudes, the theory is able to predict the initial steady-state behaviors more accurately than the later deteriorated behaviors due to the development of local and lateral torsional deformations. The theoretical skeleton curves based upon the two different skeleton stress-strain relations fit the experimental points very well mostly within a few percent deviations. The theoretical hysteresis curves also predict the experimental curves considerably well except near the sharper shoulders.

(2) The present theory is able to estimate the plastic energy dissipated during a steady-state hysteretic cycle also with a considerable accuracy. The order of magnitude of the overestimation due to the sharper shoulders mentioned above is about $10 \%$ of respective experimental values.

(3) Because of the scatter in measured strain values, it was difficult to assess the deviations of the theoretical predictions from the experimental values. It may, however, be stated that the devia- 
tions are about $20 \%$ from the respective averages of the measured strains.

(4) The idealized $\delta_{a p} \sim N_{c}$ relations derived from the present theory can not be directly compared with the experimental $\delta_{a p} \sim N_{H F}$ relations because of the difference of definitions of $N_{c}$ and $N_{H F}$ and because of the variations of strain amplitudes due to local buckling and lateral torsional deformations which were developed in specimens subjected to larger deflection amplitudes. Nevertheless the idealized $\delta_{a p} \sim N_{c}$ curves appear to have accounted partly for the fact that a pair of H-specimens of different steels with different skeleton stress-strain relations exhibit different fatigue ductility even when subjected to the same forced deflection amplitude.

\section{REFERENCES}

[1] R.D. Chipman: "Dimensionless Inelastic Bending Relationships", Experimental Mech., Vol. 20, Feb. 1963, pp. 41-46.

[2] M.J. Kaldjian: "Moment-curvature of Beams as Ramberg-Osgood Functions", J. Structural Div., Proc. ASCE, Vol. 93, ST 5, Oct. 1967, pp. 53-65.

[3] See for instance, S. Igarashi and C. Matsui : "Elastic-plastic Behaviors of Steel Members Subjected to Repeated Combined Stresses", (Part I, II) Summaries of Technical Papers of the 1969 Annual Meeting of A.I.J., pp. 1057-1060.

[4] F. Baron and M.S. Venkatesan: "Inelastic Response for Arbitrary Histories of Loads", J. Structural Div., Proc. ASCE, Vol. 95, EM 3, June 1969, pp. 763-786. 


\title{
交番塑性曲げをうける $\mathbf{H}$ 型鋼梁の荷重変位挙動と塑性疲労 (梗概)
}

\author{
一第 III 部 定 常 状 態理 論一
}

$\begin{array}{ccccc}\text { 正会員 } & \text { 棚 } & \text { 橋 } & & \text { 諒 }^{1)} \\ \text { 同 } & \text { 横 } & \text { 尾 } & \text { 義 } & \text { 貫 }^{1)} \\ \text { 同 } & \text { 中 } & \text { 村 } & \text { 恒 } & \text { 善 }^{2)}\end{array}$

\section{1. 序}

本論文の目的は，定常状態交番塑性曲げの概念と，近 似等価サンドウィッチ断面の概念に基いて，定常状態荷 重変化挙動とエネルギー吸収能力に対する近似解析解を 導く事にある。第 I 部で得られた実験結果から見て，近 似等価サンドウィッチ断面のフランジは，定常状態交番 塑性曲げにおいて，第1近似としては完全再振定歪振巾 引張圧縮をうけるものと仮定してよい。従って第部で 導かれた骨格及び履歴応力歪関倸式が適用される。本理 論から得られる数值計算結果が, 第 I 部の実験で得られ た荷重変位挙動と 1 サイクル当り消費エネルギーをかな りよく予測し得ている事が示される。絶対最大歪振巾も 本理諭で予測され得るので, 第部で導いた引張圧縮塑 性疲労延性関係式が $\mathrm{H}$ 型鋼供試体のラフンジにも適用さ れ得るものと仮定すれば, 塑性曲げ疲労延性関係式の予 測も可能である。

\section{2. 近似解析の仮定}

第I 部 Fig. 5, 6 に示される曲げ歪分布は定常状態曲 げ歪分布の存在を示している。第工部に㧊いて指摘した ように, 第 1 近似としては，定常状態曲げ歪分布が上方 及び下方曲げのいずれにも等しい振巾を有するものと仮 定する事は妥当である。この仮定は，最大あるいは最小

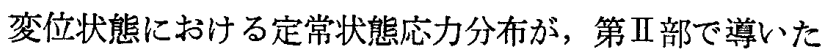

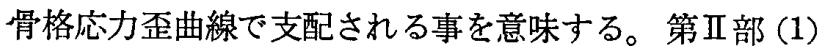
式で与えられる骨格応力歪曲線への収束過程において， 降伏歪迄は弾性応答が軟化現象を示さないと仮定した場 合の塑性域内の断面の応力分布は Fig. 1 (b) に, 第 II 部 (5) 式に基く応力分布は Fig. 1 (d) に示す。

理想化サンドウィッチ断面は, 垂直応力のみを支持す る集中断面積の両フランジと, 垂直応力を伝えずせん断 にのみ抵抗するコアとから成る。サンドウッチ断面は,

むし（1）縁歪 $\pm \varepsilon_{a}$ と曲率 $\kappa$ が同一で，(2) 対応する 縁応力 $\pm \sigma_{a}$ と曲げモーメントが同一であるならば, 元 のH型鋼断面と等価であると称される。この等価断面は 一般にその非線型応力分布に依存する。故に非線型応力 分布の如何に拘らず塑性城全体に適用され得る近似等価

1）京都大学教授 - 工博 2) 京都大学助教授 - Ph. D. (昭和 45 年 3 月 31 日本稿受理・討論期限昭和 46 年 2 月末日)
サンウィッチ断面を定義すると好都合である。この近似 等価サンドウィッチ断面とは, 塑性域内で $\sigma_{a}=\sigma_{y}$ で 且 $\varepsilon_{a}=\varepsilon_{y}+\varepsilon_{p y}$ である特定の断面においてのみ等価条件を すべて満足しているように等価集中断面積が決定された 断面と定義される。この特定断面以外は正確には等価条 件が満足されないという意味で近似等価と称する。

等価条件は弾性域では正確に満足され, フランジ集中 断面積は (1) 式で与えられる。塑性域では前述の定義か ら, 近似等価集中断面積は $(2 \mathrm{a} \sim \mathrm{d})$ 式で与えられる。 この時の応力分布に対応するモーメントを $M_{y}$, 弾性限 モーメントを $M_{0}$ で記す。また， $M_{y} / M_{0}$ の比を $\mu_{0}$ と 記す。Fig. 1 (d) に示す応力分布に基く近似等価サンド ウィッチ断面のフランジ集中断面積は $(2 \mathrm{~b}, \mathrm{c})$ 式の $n$

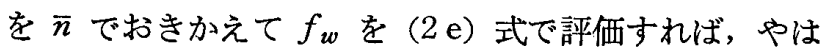
り (2a) 式で与えられる。この時の応力分布に対応する モーメントを $M_{s}, M_{s} / M_{0}$ の比を $\mu_{s}$ で表わす。

\section{3. 定常状態解}

3.1 骨格荷重変位曲線-1 前記の 仮定と 理想化に よって, $\mathrm{H}$ 型鋼梁は弹性域ではフランジ面積 $A_{e}$, 塑性 域では $A_{p}$ を有するサンドウィッチ梁として扱われる。 Fig. 2 のような座標系と記号を用い，(3) 式の無次元量 を用いる。Fig. 2 (a) の片持梁の弾性域, 塑性域の下フ ランジ応力は夫々 (4)，(5) 式で与えられる。定常状態に 達して後の最大変位位置におけるフランジ応力状態は骨 格応力歪曲線で支配されると考えられる。弾性域では繰 返軟化現象を示さないと仮定すると，第部で導かれた 骨格応力歪関倸式 (7) は塑性域にのみ適用される。(4), (5)，(6) 式から, 弾性域と塑性域に対するたわみ曲線の 微分方程式は夫々 (9)，(10) 式で与えられる。境界条件 之連続条件を満足する解は（11）式で，変位振巾と荷重 振巾の関係は (12) 式で与えられる。(13)を(12) 式 から引けば（14）式の塑性変位振巾の表現を得る。

3.2 履歴荷重変位曲線上記の骨格荷重変位曲線 上の一点 $\left(\delta_{a}>0, q_{a}>0\right)$ で表わされる変形状態から 発する荷重変位曲線が その骨格曲線上の対称点 $\left(-\delta_{a}\right.$, 一 $q_{a}$ ) を通過するならば，そして $\left(-\delta_{a},-q_{a}\right)$ におけ る変形状態が丁度 $\left(\delta_{a}, q_{a}\right)$ の変形状態を表わす関数に 負号を付した関数で表わされるならば，確かに閉じた定 
常状態履歴ループが存在する。この際の塑性域内の断面

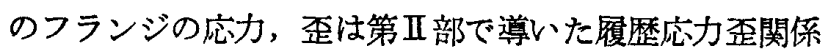
式で支配され，対応する曲率 モーメント関係式は (16) 式で与えられる。塑性域のたわみ曲線の微分方程式は （17）式で，境界条件と連続条件を満足する解注 (18) 式 で夫々与えられる。履歴荷重変位曲線は (19) 式で表現 され，確かに骨格曲線上の対称点を通る事，且その变位 位置で確かに負号を付した関数で表わされる変形状態に なっている事が確められる。従って前節に述べた収束過 程を経て骨格曲線上の一点で表わされる变形状態に達し たならば，以後の荷重の荷重変位曲線は（19）式で表わ される曲線と他半分から成る閉じた履歴ループである。 この履歷ループは, 現実の荷重変位曲線が何サイクルか の後に近づく漸近曲線である。

\section{3 塑性エネルギー消費 （12）式と（19）式に基} いて定常状態 1 履歴サイクル中に片持梁の中で消費され る塑性エネルギーは (20) 式で評価され得る。

$3.4 \delta_{a p} \sim N_{c}$ 関係式 指定された变位振巾に対す る荷重振巾が (12) 式で求められると，(5)，(7) 式から 歪も評価できる。最大縁歪とその塑性成分とは $(22 \mathrm{a}, \mathrm{b})$ 式で与えられる。もしこの歪評価が正確で, 且ここで求 められた縁歪の塑性成分に対して第部の (7) 式の塑性 歪振巾一刍裂発生回数関係式が適用されてよいならば, 塑性変位振巾一亀裂発生関保式の近似式が得られる。

\section{5 骨格荷重変位曲線-2 第开部の (5) 式の骨格} 応力歪関係式がこの問題に適用されるならば, 骨格荷重 変位曲線は (23) 式の形に帰せられ, 最大絶対縁歪とそ の塑性成分は (24) 式で与えられる。

\section{4. 数值計算結果とその検討}

表 1 は，すべてのH型鋼供試体の断面性状，材料性質 及び実験結果の無次元化データを示す。降伏応力は供試 体毎に異なるが，引張圧縮試験は 2 体のH型鋼供試体か ら採取した板状試験片について行ったのみである。他方 処女荷重変位曲線が完全塑性挙動を示したので全塑性モ ーメント值に達したものとして降伏応力を逆算した。材 料の骨格応力歪曲線はシリーズ每に同しと仮定した。

理論的な骨格荷重変位曲線は, 各 H供試体について, (14)，(23）式を用いて描く事ができる。Fig. 3 (a)，(b) は夫々, Series A, B に対する理論的骨格荷重変位曲線 と実験点の両対数プロットを示す。表 1 に示すように, すべての $\mathrm{H}$ 供試体の $M_{s}$ の值は夫々, 対応する $M_{y}$ の 值に非常に近いので, Fig. 3 のスケールでは $M_{s} / L$ を $M_{y} / L$ と同じと見なしてよい。(14)，(23）式で予測さ れた供試体每に異なる理論的骨格荷重変位曲線は，殆ん どの実験值に対して数\%の差を認めるに過ぎない。

Fig. 4 は (19) 式で与えられる 3 個の履歴荷重変位 曲線と対応する実験履歴ループを示す。Fig. 5 (a)，(b)
は，無次元化された実験点と比較さるべき理論的履歴荷 重一塑性変位曲線の両対数紙上表示である。明らかに， 理論曲線はや〉鋭い眉部分を除いて，実験結果をかなり 上く予測し得ている。

1 履歷サイクル当り消費される塑性エネルギーは(21) 式で計算される。Fig. 6 に图示した理論的評価は実験 点を結ぶ值線とかなり近く, その過大評価の程度は約 10\%である。1 サイクル当り消費エネルギーと塑性変 位振巾との間の関係は簡単な表現に帰せられないが,

（25）式の評価にかなり近い。

スパン中央から $6 \mathrm{~cm}$ 離れた断面において計測された 歪と（10）式 (24) 式による理論的予測值の比較を Fig. 7 に示す。計測值が等しい歪振巾でないために, 理論值 と実験值の差を表現する事は困難であるが, 計測歪の平 均值からの理論值の偏差は約 $20 \%$ 程度と云える。

最大縁歪が第部 (7) 式の塑性疲労延性関係式に従う と仮定するとすべてのH型鋼供試体の曲げ塑性疲労延性 関係式 $\left(\delta_{a p} \sim N_{c}\right)$ が得られる。(14),(22) 式と (23), (24) 式から計算された $\delta_{a p} \sim N_{c}$ 曲線は Fig. 8 で実線 と鎖線で示されている。これらの理想化された $\delta_{a p} \sim N_{c}$ 関係式が, 実験で得られた $\delta_{a p} \sim N_{H F}$ 関保式と比較さ れる際に注意すべきは, $N_{c}$ と $N_{H F}$ の定義の差, 大変 位振币時の局部座屈, 横征れ変形に伴う歪の局部的增大 による疲労寿命の低下等である。これらの条件にも拘ら ず， $\delta_{a p} \sim N_{c}$ 関係曲線は実験結果の傾向を或る程度解明 し, 骨格応力歪曲線の差が，曲げ塑性疲労延性の差を説 明し得る一因子である事を示した。

\section{5. 結}

\section{諭}

（1）第1近似としてここに提案された定常状態理論 は，交番強制定变位を課せられるH型鋼部材の定常状態 荷重変位挙動をかなりの精度で予測し得る。2 個の異な る骨格応力歪関係式に基く骨格荷重変位曲線は, 実験点 に対して多くは，数 9 程度の偏差で非常によく合う。理 論的履歷荷重変位曲線は, やや鋭い肩部以外は実験曲線 をかなりよく予測し得ている。

（2）本理論はまた定常状態の一履歴サイクル当り消 費される塑性エネルギーをかなりの精度で評価し得る。 過大評価の程度は約 10\% である。

（3）実験で計測された歪の平均值に比較して，同位 直の歪の理論的予測値の偏差は $20 \%$ 程度である。

（4）本理論から導かれた $\delta_{a p} \sim N_{c}$ 関保は前節で述 べた理由により実験で得られた $\delta_{a p} \sim N_{H F}$ 関係と直接 比較され得ないが，理想化された $\delta_{a p} \sim N_{c}$ 関係性，異 なる骨格応力歪曲線を有する異なる SS 41 鋼材の一対 のH型供試体が同一の変位振币の試験でも異なる塑性曲 げ疲労延性を示した事実の理由を部分的に明らかにした と思われる。 
In the previous paper, the author reported the theory of the Chain Construction with elastic joints from the results of the experimental study on the Sandwich Curtain Wall. It was shown that the theory could be applied to the wall with close approximation in its vertical direction. From the results of the other experimental study, it was shown that the theory could be applied to the each and every construction with elastic joints (Chain Plate).

The present paper shows that this theory could be applied to the new Building Element consisted of slab unit and ceiling unit, by the experimental study on this Building Element. And approachability of limit analysis on the Building Elemeut are found to be possibe as the result of an experiment on the element with special joints.

U.D.C. $624.042 .7: 624.043$

STUDY ON ASEISMATIC ELASTIC DESIGN BY STATISTICAL METHOD

by YOSHIAKI NAKAO, Mizubushi Heavy Industries Ltd., Member of A.I.J.

Such steel structures as steel stacks, boiler frames, etc. are usually designed by the elastic theory. The author tried to establish the method of the aseismatic elastic design by statistical method.

First be derived the formulae to estimate the response of general structures to the ground motion of two perpendicular directions, assuming that the seismic phenomena is a steady, Gaussian, and ergodic process. These formulae are proved to have sufficient accuracy by the random shaking table tests for the models of several framed structures. Second he applied the theory to the actual seismic waves, introducing the concept of the average earthquake continuation time.

Finally a practical response specrum is proposed, which covers the whole response range to the seismic wave recorded in the past.

U.D.C. $624.014 .2: 539.37$

LOAD-DEFLECTION BEHAVIORS AND PLASTIC FATIGUE OF WIDEFLANGE BEAMS SUBJECTED TO ALTERNATING PLASTIC BENDING

-Part III, Steady-State Theory-

(See Page 35)

by Dr. RYO TANABASHI, Prof. of Kyoto Univ., Dr. YOSHITSURA YOKOO, Prof. of Kyoto Univ. and TSUNEYOSHI NAKAMURA, Assistant Prof. of Kyoto, Members of A.I.J. 